\title{
Employee Training and Education
}

\author{
KATJUŠA KOSTANJŠE K \\ International School for Social and Business Studies, Slovenia \\ kostanjsek.kaja@gmail.com \\ GREGOR JAGODIČ \\ International School for Social and Business Studies, Slovenia \\ gregor.jagodic@mfdps.si
}

In the past, it was paramount for employers that employees were obedient and followed the instructions, while today they are expected to bring added value to the organization in terms of knowledge, experience, skills and innovation at work. All this is acquired through training and education throughout the life of the employees. The research was intended to check how organizations understand employee training and education. We were particularly interested in the transfer of skills to newly hired employees during the probationary period. Based on the conducted research, we have confirmed our hypothesis that the majority organizations choose trainings during the probationary period.

Key words: employee training, education, transfer of skills, organization, HRM

(cc)BY-SA https://doi.org/10.26493/1854-4231.15.43-56

\section{Introduction}

In the past, the most important thing for employers was that the employees blindly followed the instructions of their superiors, were obedient and responsive. Today, employees are expected to bring new knowledge, experience, skills to the organization and to be as innovative in their work as possible. All this gives the organization new added value and increased competitiveness in the market. We all learn throughout our lives, whether at home, at work or anywhere else. Particularly, we acquire a great deal of expertise through training or education in our work environment. It is here that organizations are working hard to get a new employee (or existing one) trained for a (new) job as well as possible so that he or she can work independently as soon as possible and that his or her job is successful.

We have methodologically prepared the content of the article we have used a qualitative and quantitative research method. We also used primary and secondary data sources. They were obtained 
from pre-existing literature and through a questionnaire. The research work was divided into theoretical and empirical part, where different research methods were used for each.

The purpose of the research was to investigate and determine which method of training is most commonly used by Slovenian employers. Then, through research and analysis, interpret the obtained data and verify compliance with our hypothesis.

We set out the following hypothesis:

H1 Slovenian employers, as the most common method of on-the-job training, use training during the probationary period.

We assumed that the heads of human resources or departments of human resources management of Slovenian organizations are ready to participate in the survey and the data obtained will be honest, especially since it is an anonymous survey. We also assumed that the information obtained would allow us to refute or confirm our hypothesis. We saw the limitations of the survey mainly in the nonresponse of the respondents, which could affect the sample representativeness. We have taken care of the latter in a way that we have covered more Slovenian organizations and ensured the adequacy of communication through various communication channels. We also saw limitations in a large number of incompletely filled surveys, which we tried to solve by designing a questionnaire that was transparent and least time-consuming.

\section{A New Employee Employment and Recruitment}

The recruitment of a new associate begins when the selection is completed. When we submitted the proposal to the selected candidate, we also made a crucial first step. This is followed by a referral to a medical examination, signing of a contract and registering a new associate for compulsory pension and disability health insurance. This also begins the employment relationship and the introduction of the individual into the work environment.

Employee deployment is one of the most important processes for the development of an individual, with which our purpose is to achieve the overall success and effectiveness of the associate and his/her ability to perform work independently. For these reasons, deployment must be organized at a high professional level, planned and very systematic. Only with such deployment can the employee be expected to perform their duties independently. At the same time, he or she will be satisfied, innovative and able to adapt to changes in the new environment (Mihalič 2006, 168). 
Starting a new job presents stress to the individual and it can also be a difficult process. The new associate must begin to face new tasks while getting used to the new organization, work environment, coworkers, and sometimes new living environments as quickly as possible. And in all this, the process of introducing an individual is of great help (Coleman 2013).

In practice, employers decide to introduce employees upon their employment. However, they forget that it is also advisable to do so when working methods change, with horizontal promotion or when redeploying existing employees to other jobs. Each job has its own work process, its responsibilities, procedures etc. (Mihalič 2006, 168).

\section{Steps for Introducing Employees}

There are differences between systematic approaches in practice. It is mainly about the different complexity of individual work tasks, as well as the fact that organizational structures differ from organization to organization. At the same time, whether we are introducing a new employee or an existing one plays an important role. The latter requires shorter introductions, while the former need longer and more in-depth work. Regardless of what is written, certain basic procedures must be followed in each deployment (Mihalič 2006, 169). However, it should be remembered that systematic introduction to a new environment can significantly shorten the process of socialization or enable an individual to achieve the expected results faster (Svetlik 2002, 166-7).

For a newly hired person, the first introduction step is a preliminary introductory interview. It is provided by the human resources department on the first working day of the employee. This step is referred to as the macro deployment level, as the newly recruited person acquires a wide range of information, namely: basic information of the organization, organizational structure, organizational units, core products or services of the organization etc. The employee is also made aware of all the rights and obligations applicable to all employees (e.g. code of ethics, working hours, social security, breaks, annual leave, etc.). It is certainly important that the introductory interview is conducted in a relaxed and friendly spirit (Mihalič 2006, 169-70).

The second step is called the mezzo deployment level and involves a preliminary introductory interview between the new employee and the head of the organizational unit. The purpose of the interview is to give the new associate a closer look at the organizational unit structure, its organization and functioning (Mihalič 2006, 170). 
The third and final step is called the micro level of deployment and is performed by the directly superior, sometimes also the associate who will be in charge of the deployment. During this level of deployment, the new employee becomes familiar with the deployment plan and program, with well-defined rights, duties and obligations. We can also give him a more detailed insight into the characteristics and types of tasks, as well as introduce him to the work post, colleagues, team members ... After that a regular introduction begins for the new associate (Mihalič 2006, 170).

\section{Employee Deployment Contractors}

The introducer is the person who plays the most important role during the deployment of an existing or new employee. He or she is responsible for successful and efficient implementation. At the same time, it ensures that the program and the plan are implemented as correctly and systematically as possible. When selecting an introducer, the directly superior is the best option, especially in terms of avoiding separation between introduction and management. At the same time, there is no duplication of delegation, organization of work, reporting and questioning of responsibilities (Mihalič 2006, 172).

The deployment process should be organized and standardized in every organization, but many times that is not the case. Too often it happens that a new co-worker is left to be introduced to random disinterested co-workers, or even to himself, because he is not introduced by anyone and forced into self-introduction. Such deployments pose a high risk to the organization, since the new associate can take over the rules, habits, way of working, etc. which are introduced in the working group, but they are often completely inadequate or incorrect. Introductions that begin in this way are absolutely inadequate (Mihalič 2006, 172-3). If the implementation is not done well, the negative consequences may also be that the employee does not know for a long time in what kind of organization he is working, is not satisfied with the work, has no motivation to work, does not know his role in the organization, it does not integrate into the organizational culture, perform worse and not identify with the values of the company (Florea 2014, 13-23).

\section{Employee Deployment Program and Plan}

Deployment programs are prepared by the introducer in collaboration with the HR department and differ depending on whether we are introducing a new associate or an existing one. A great difference 
in the program is the complexity of the job, including the degree of complexity of skills that an individual has to have to perform their job and tasks effectively. Each deployment program should be divided into two parts, the general part and the professional part, with the general part covering e.g. the following (Mihalič 2006, 173-4):

- basic information of the organization,

- presentation of the organization's activities,

- presentation of the organization's products or services,

- acquaintance with main rights and obligations that apply to all employees,

- getting acquainted with main rights and obligations related to the associate's working post,

- presentation of basic organizational units and organizational structure,

- complete organization tour and individual units,

- presentation of the organization's management and individual leaders,

- introducing new colleagues,

- presentation of the program and the deployment plan,

- accurate presentation of the job, its characteristics and requirements,

- presentation of work equipment,

- acquaintance with the safety at work of the chosen workplace,

- acquaintance with the possibility of promotion, rewards, additional education, etc.

The above list is valid only when a new associate is hired. The introduction of a co-worker who was reassigned, or in the same workplace only changed the methods or procedures of work, shortens the list significantly.

The content of the professional part cannot be generally defined. This part depends on the type of job tasks of the particular job, the complexity of the job, the education required for that job, the competencies that the associate needs, and so on. Therefore, only the following points can be identified (Mihalič 2006, 174):

- become familiar with all procedures and processes related to the employee's workplace,

- learn about ways of performing work effectively,

- get to know all the associates he will work with, 
- learn how to properly use work tools, appliances and accessories,

- get to know what regulations, acts and regulations it must follow,

- get to know what criteria and standards for excellence and good work are relevant to his or her workplace,

- get to understand the role and importance of his/her work tasks at the level of success of the whole organization and

- to find out what occupational safety requirements apply to his/her workplace and what are the ways of protecting the health of self and colleagues.

It is necessary to keep in mind that all those tasks that the employee will have to perform independently and those he/she may encounter after the completion of the introduction (Mihalič 2006, 175) should be included in the professional part of the deployment program.

The individual tasks and phases in the professional part of the deployment program need to be defined in the plan. The duration of the program depends entirely on the complexity of the work tasks for which the individual is being introduced. However, it should be borne in mind that the input energy and time of the introducer are the ones that contribute to deployments quality (Mihalič 2006, 175). It is important that an evaluation is carried out after the end of the program so that the content of the program can be improved in the future (Coleman 2013).

\section{Developing Employees Training and Education}

The new age and knowledge management have also brought changes in employee training. If once knowledge gained in school was enough for employment, that is no longer the case today. Today employees are expected to constantly upgrade and supplement their knowledge, gain new experience and skills, and help the employer to achieve the set goals. It is also expected that, when hiring, we will integrate as quickly as possible into the work environment and, during the introduction and training, will acquire the necessary knowledge to work as independently as possible in the chosen job.

In practice, in modern times, when we talk about education, we often come across related terms, such as perfecting, training, continuing education, lifelong learning, and more. The denominator is the same for everyone, all of them are planned, goal-oriented and practical knowledge acquisition (Mihalič 2006, 188), separated only 
by minimal differences. However, all of them are related to the professional, work and personal development of individuals, as well as their efficiency in work tasks and performance (Dermol 2010, 31). The role of training is therefore to impart knowledge, perfect knowledge, develop individuals and change behavior.

However, before proceeding, let's look at the mentioned differences (Mihalič 2006, 190):

- Education is a systematic and planned process. The employee develops and acquires general, professional, and scientific knowledge, skills, habits, abilities and other competences.

- Perfecting is a process that is carried out in a systematic, planned and targeted manner. The employee supplements, changes, deepens, expands and systemizes previously developed general, professional, including scientific knowledge, skills, habits, abilities and other competences.

- Training is the process by which an employee develops and acquires specific knowledge, skills, habits, abilities and other competencies. All that is needed is the employee to be able to perform his work successfully and efficiently.

Let's look at what differentiates training from deployment (Jereb 2002, 175-212):

- Training can be understood as an intermediate stage between education and work or as additional training for those skills and habits that are required to perform a particular job within the whole of an activity.

- Deployment on the other hand, is more focused on enabling effective recruitment of new employees and those employees whose working conditions have changed. It refers to learning about the basic processes, customs and rules in an organization that allow a newcomer to be able to integrate with them qualitatively.

Knowledge can be acquired in many ways, but theoretically classified as internal and external. We both know different forms, namely: independent or individual training, perfecting and education, teamwork, teamwork and a combination of all of the above (Mihalič 2006, 190).

Subsequently, it is sensible to further specify which types of knowledge acquisition are fundamental in the context of internal training, perfecting and education, and which in the external. Internal trainings, perfecting and educations are (Mihalič 2006, 190): 
- training during the practice,

- new employee training during the probationary period,

- employee training of during internships,

- employee training at work and on the job,

- training (and education) during the deployment of new employees or associates;

- internal training, perfecting and education that are functional in nature.

External trainings, perfecting and education are as follows (Mihalič 2006, 191):

- training in courses, seminars, conferences, symposia, professional lectures etc.,

- freelance training, further training and education,

- education on and off the job and

- external training, perfecting and education that are functional in nature.

Each training is recommended to be carried out systematically. Such approach enables the training and development of the individual to achieve its purpose and to follow the logic of carrying out successive steps. A systematic approach or training is a four-stage process that consists of (Vukovič and Miglič 2006, 71):

- analyzing training needs,

- developing training plans,

- realization of plans or implementation of training and

- evaluation of results or evaluation of training and obtained results.

\section{Modern Forms of Training, Perfecting and Education}

Nowadays, modern forms of education include: e-education or distance education, simulation education, rotational training or rotation, extreme education, role-playing and case study, frontal formats, programmed learning, on-the-job method, 4-step method, case study, coaching, etc. All forms are quite widespread, but the choice depends on the type and purpose of the organization (HR 2001).

In Slovenian and especially international organizations, they often use simulation training or education to acquire new knowledge. This format is about acquiring knowledge based on the simulated diverse situations that employees face on a daily basis inside or outside the 
company in the course of their work. Most often, this type of education is used in teambuilding, employee training, when we want to research and determine how our co-workers or employees will react in crisis situations or to potential changes etc. (Mihalič 2006, 191).

In organizations that also deal with the development of their employees, they most often choose a form of training called rotation. Rotary training is particularly relevant when developing future leaders, as they require a wide range of skills. We also choose to rotate if we want to develop members of effective teams. In this case, the rotation objective allows each member to replace the other member. This form of gaining new knowledge is best reflected in cases where we need to allocate employees to jobs where it should be considered that we rotate each individual to the position that is appropriate for him and for the organization. Namely, it is precisely during the course of a replacement that it is most often shown that an individual is much more successful in the workplace, where he or she would not be allocated at first (Mihalič 2006, 191).

\section{Research and Management Suggestions}

Our research, among other things, was intended to investigate and determine which method of on-the-job training is most commonly used by employers and to verify our hypothesis by analyzing and interpreting the data obtained.

\section{METHODS AND CHARACTERISTICS OF THE SAMPLE}

We used quantitative research for verification purposes. The survey was conducted with the help of a survey questionnaire, which was created in the web application $1 \mathrm{KA}$. To interviewed companies we sent an e-mail to their publicly available e-mail addresses explaining the purpose of the survey and adding a link to access the survey website, specifically to the heads of human resources and heads of human resources management departments.

The sample or population was represented by Slovenian companies of different sizes and selected activities, which were published in the electronic format of TDS (Telephone Directory of Slovenia), while trying to follow the structure of entities in reality (company size). 5,000 companies from different industries were randomly selected. The survey was conducted between June 30 and July 9, 2019. $830(16.6 \%)$ respondents answered the survey and $339(6.78 \%)$ respondents filled it out.

The collected data were analyzed using the spss software tool, and the results were presented using tabels. Descriptive statistics were 
TABLE 1 Overview of Survey Completion Data with Respect to Completion of Survey Completion

\begin{tabular}{rrrrr}
\hline Completed & $\begin{array}{r}\text { Partially } \\
\text { completed }\end{array}$ & $\begin{array}{r}\text { Total } \\
\text { appropriate }\end{array}$ & $\begin{array}{r}\text { Total } \\
\text { inadequate }\end{array}$ & Total \\
\hline 284 & 55 & 339 & 491 & 830 \\
\hline
\end{tabular}

used to determine the characteristics and composition of the sample, and the hypothesis was tested using inferential statistics. First we used the calculation of $\chi^{2}$ for the variables tested and their distributions, but since the latter was not uniform, we used the largest percentage of the possible answers to test the hypothesis.

The limitations of the survey were, in the end, reflected in the respondents' perceived unresponsiveness and in the large number of incorrectly or incompletely filled surveys.

\section{BASIC ANALYSIS OF DATABASE VARIABLES}

First we asked the respondents about the industry, size and age of the company, the number of employees and the region of the company's headquarters. A total of 339 questionnaires were completed (table 1). 182 (53.7\%) micro, 97 (28.6\%) small, 49 (14.5\%) medium-sized and $11(3.2 \%)$ large companies participated in the survey. In the sample structure, the proportion of large firms was larger than the structure in reality, but large firms had greater employment needs.

According to the industry 78 (23\%) companies come from construction, 62 (18.3\%) in motor trade, maintenance and repair of motor vehicles, $39(11.5 \%)$ in manufacturing, $35(10.3) \%)$ in the catering industry, 22 (6.5\%) in transport and storage, and 103 (30.4\%) in other industries.

According to the region from which the surveyed companies come, 119 companies come from central Slovenia (35.1\%), 44 from Gorenjska (13\%), 37 from Podravska (10.9\%), 35 from Savinjska (10.3\%), 23 from Goriška (6.8\%), 15 from the Coast and Karst (15\%), from Koroška and Notranjska each 13 companies (3.8\%), 12 from Posavje (3.5\%), 10 and 11 (2.9\% and 3.2\%) from Pomurje and Primorskonotranjska and from Zasavje 7 (2.1\%). The result obtained is also expected, as the largest number of companies is registered in central Slovenia, and Zasavje region is a rather small area.

Our research hypothesis was: Slovenian employers use training during the probationary period as the most common method of onthe-job training.

In the questionnaire we also asked the respondents which methods are most often used to train (new) employees. Companies had 
TABLE 2 Employer-Selected Training Methods

\begin{tabular}{lrrrrrr}
\hline Item & & $(1)$ & $(2)$ & $(3)$ & $(4)$ & $(5)$ \\
\hline Sample & Valid & 296 & 296 & 296 & 296 & 296 \\
& Missing & 43 & 43 & 43 & 43 & 43 \\
\hline Average & 3.98 & 4.20 & 2.74 & 3.16 & 2.60 \\
Asymmetry & -1.168 & -1.434 & 0.209 & -0.252 & 0.328 \\
Standard flattening error & 0.142 & 0.142 & 0.142 & 0.142 & 0.142 \\
Minimum & 1 & 1 & 1 & 1 & 1 \\
Maximum & 5 & 5 & 5 & 5 & 5 \\
\hline
\end{tabular}

Notes Column headings are as follows: (1) during practice, (2) during the probationary period, (3) during internship, (4) during internal training, (5) courses, seminars, conferences.

TABLE 3 Calculation of $\chi^{2}$ for the Checked Variables and Their Distributions

\begin{tabular}{lrrrrr}
\hline Item & \multicolumn{1}{c}{$(1)$} & $(2)$ & \multicolumn{1}{c}{$(3)$} & \multicolumn{1}{c}{$(4)$} & $(5)$ \\
\hline$\chi^{2}$ & $195.081^{*}$ & $256.568^{*}$ & $47.514^{*}$ & $14.034^{*}$ & $34.034^{*}$ \\
Level of freedom & 4 & 4 & 4 & 4 & 4 \\
Asymptotic characteristic & 0.000 & 0.000 & 0.000 & 0.007 & 0.000 \\
\hline
\end{tabular}

Notes Column headings are as follows: (1) during practice, (2) during the probationary period, (3) during internship, (4) during internal training, (5) courses, seminars, conferences. 0 cells $(0.0 \%)$ have an expected frequency of less than 5 . The minimum expected cell frequency is 59.2 .

methods listed and each had to choose a value from 1 to 5 , where 1 meant that they never used these methods and 5 that they always used them. As can be seen from table 2, the most commonly used method was 'training during the trial period' (4.20). This was followed by the 'training during practis' method (3.98), as the least used companies chose the training method through courses, seminars, conferences, etc. (2.60). This question was answered by 296 respondents. This is also the number of all who answered 'yes,' in the previous question, 'Do you have a process for deployment for a (newly) hired person to your business?'

As shown in table 3, the distribution is not uniform, so we will consider the largest percentage of possible answers to test the hypothesis.

Table 4 shows in numerical terms how many companies chose to use training during the trial period 'always' (160 companies, 54.1\%) and 'almost always' (74 companies, 25.0\%). According to the result, almost $80 \%$ of companies mainly use it.

Training during the probationary period is generally and consistent with the findings of the theoretical part of the article (Mihalič 
TABLE 4 Frequency of Employer-Selected Training Methods

\begin{tabular}{llrrr}
\hline Item & & $(1)$ & $(2)$ & $(3)$ \\
\hline Valid & 5 (always) & 160 & 47.2 & 54.1 \\
& 4 & 74 & 21.8 & 79.1 \\
& 3 & 36 & 10.6 & 91.2 \\
& 1 (never) & 14 & 4.1 & 95.9 \\
& 2 & 12 & 3.5 & 100.0 \\
& Total & 296 & 87.3 & \\
\hline Missing & Interrupted & 43 & 12.7 & \\
Total & & 339 & 100 & \\
\hline
\end{tabular}

Notes Column headings are as follows: (1) frequency, (2) percentage, (3) cumulative percentage.

$2006,190)$, one of the most frequently selected forms of training for new employees. Similar findings can be drawn from our research, so we can confirm the hypothesis.

Almost $80 \%$ of the surveyed companies (79.1\%) therefore chose training during the probationary period as the most common method of training new employees, which is why we confirmed the hypothesis. The confirmation was expected because, as we have already stated in the theoretical part, Slovenian companies in general use the possibility of probationary employment as an employee training, in which they can judge the success of cooperation with the new employee and their integration into the working environment and adaptability to working conditions, which also means successful knowledge and skill transfer (Florjančič, Bernik, and Novak 2004, 80-81; Papalexandris and Panayotopoulou in Murn and Kovač Zaplotnik 2011, 22-23; Spacey 2018). In our opinion, it is important for the company to get to know a new employee through the probationary period and to explore the possibilities of mutual cooperation in the future of a particular job.

\section{Management Suggestions}

Based on the findings of our research, we suggest that Slovenian employers should continue to decide on the method of staff training during the probationary period. Regardless of the statements of different authors, we believe that the trial work should be entirely based on the organization's best efforts to introduce and deploy a new associate qualitatively and quantitatively into the work environment and to be able to perform new work tasks. Regardless of how well the individual is trained and what kind of experience they have, he is coming to a new environment where new rules apply, a differ- 
ent organizational culture is established, and also there are different people. An individual's job performance and his/her early acquisition of the necessary skills, and finally his/her transfer of knowledge to the rest in the group, in the new work environment absolutely depends on his/her training, support of the organization and influence on his/her successful integration. Those organizations that have not yet decided for training for any reason, we suggest that they consider introducing training during the probationary period, thereby improving the involvement of new employees in existing working environments.

\section{Conclusion}

With the help of our research we wanted to research and identify which or what are the training methods most often decided by Slovenian employers. With the help of a questionnaire and a subsequent analysis of the hypothesis we found that the surveyed companies confirmed our hypothesis that they use training during the probationary period as the most common method of training on-the-job staff. This finding is also consistent with the opinions of various authors, who state that such deployment or training is the most optimal for both, the new employee and the company and produces the best results.

Since the structure of our survey sample followed the structure of companies in the Slovenian economy, with the share of large companies in the sample being slightly larger than the real one in the structure of the economy, it can be argued that the findings of our research apply to the entire Slovenian territory.

As mentioned above, the training of new employees within the trial period, based on the conducted research, plays an important role in faster transfer of knowledge, better involvement of new employees in the work environment, and significantly contributes to the transfer of knowledge and skills. In doing so, the organization also provides good practice in connecting existing and new employees.

\section{References}

Coleman, J. 2013. Induction for New Employees Procedures. Shetland: NHs Shetland.

Dermol, V. 2010. 'Usposabljanja zaposlenih ter njihov vpliv na organizacijsko učenje in uspešnost v slovenskih storitvenih podjetjih.' $\mathrm{PhD}$ dissertation, University of Ljubljana.

Florea, N. V. 2014. 'Good Practices of Integration for New Employees in Romanian Organizations.' Buletin Stiintific 37 (1): 13-23. 
Florjančič, J., M. Bernik, in V. Novak. 2004. Kadrovski management. Kranj: Moderna organizacija.

HR. 2001. 'List of Training Methods.' https:/www.hr.com/en/ communities/training_and_development/list-of-training-methods _eacwezdm.html

Jereb, J. 2002. 'Izobraževanje in usposabljanje kadrov.' In Management kadrovskih virov, edited by S. Možina, 175-212. Ljubljana: Fakulteta za družbene vede.

Mihalič, R. 2006. Management človeškega kapitala. Škofja Loka: Mihalič in Partner.

Murn, M., in T. Kovač Zaplotnik. 2011. 'Vloga vodje in kadrovske službe pri motiviranju in nagrajevanju zaposlenih.' Master's thesis, Univerza v Ljubljani.

Spacey, J. 2018. '8 Types of Knowledge Transfer.' https://simplicable.com /new/knowledge-transfer

Svetlik, I. 2002. 'Pridobivanje, izbiranje in uvajanje delavcev' In Management kadrovskih virov, edited by S. Možina, 166-7. Ljubljana: Fakulteta za družbene vede.

Vukovič, G., and G. Miglič. 2006. Metode usposabljanja kadrov. Kranj: Moderna organizacija. 